\title{
RESENHA
}

\section{ORALIDADE E LETRAMENTO}

Referência da obra resenhada:

MARCUSCHI, Luiz Antônio. Da fala para a escrita: atividades de retextualização. $5^{a}$ edição. São Paulo: Cortez, 2004. 133p.

\section{Maria de Fátima Berenice da Cruz ${ }^{1}$}

Luiz Antônio Marcuschi, professor titular da Universidade Federal do Pernambuco, pós-doutor pela Universitat Freiburg na Alemanha e Doutor em Letras pela Universitat Erlangen-Nurnberg, também na Alemanha, atualmente desenvolve a pesquisa "Fala e escrita: características e usos".

A obra Da fala para a escrita: atividades de retextualização está dividida em duas partes. A primeira, que o autor intitula de "Oralidade e Letramento" está dividida em oito tópicos. No primeiro tópico "Oralidade e letramento como práticas sociais" o autor inicia afirmando ser impossível investigar oralidade e letramento sem vinculá-los às práticas sociais da civilização contemporânea. Assim como já se torna impossível observar as semelhanças e diferenças entre fala e escrita sem considerar a distribuição de seus usos na vida cotidiana. Para ele a predominância dos estudos a partir dos anos 80 , concebe oralidade e letramento como atividades interativas e complementares no contexto das práticas sociais e culturais.

$\mathrm{O}$ autor considera que as línguas se fundam em usos. Assim sendo, o letramento, enquanto prática social formalmente ligada ao uso da escrita, tornou-se indispensável, elevando-se a um status mais alto, chegando a simbolizar educação, desenvolvimento e poder. Contudo, ele salienta que se observarmos a realidade humana, seria possível definir o homem como um ser que fala e não como um ser que escreve. Mas nem por isso seria a oralidade superior à escrita.

Em vista disso, Marcuschi acentua que a escrita não pode ser tida como uma representação da fala, visto que não consegue reproduzir muitos dos fenômenos da oralidade. Ele lembra que todos os povos, indistintamente,

${ }^{1}$ Professora titular da Universidade do Estado da Bahia. Professora do Programa de Pós-Graduação em Crítica Cultural. Líder do GEREI/CNPq-UNEB. E-mail: fatimaberenice@terra.com.br. 
têm ou tiveram uma tradição oral, mas poucos tiveram ou têm uma tradição escrita. E ratifica que este dado não valida a supremacia da oralidade sobre a escrita. O tópico I é finalizado com uma referência à fala (enquanto manifestação da prática oral) como aquisição em contextos informais do diaa-dia. A escrita (enquanto manifestação formal do letramento) é referida como um elemento adquirido em contextos formais: na escola.

No tópico II, "Presença da oralidade e da escrita na sociedade", Marcuschi lembra que a presença da escrita permeia quase todas as práticas sociais dos povos, até mesmo os analfabetos estão sob a influência das práticas de letramento; daí a estreita relação que existe entre escrita e contexto, devendo a escola usar deste recurso com maior maleabilidade. No que diz respeito ao ambiente familiar, o autor indaga: que uso da leitura e da escrita é feito em casa? E para que se usa a leitura e a escrita em casa? Para ele, seja qual for a resposta é necessário perceber fala e escrita como atividades comunicativas que representam o uso real da língua.

No tópico III, intitulado "Oralidade versus letramento ou fala versus escrita"? nos é apresentado a distinção entre duas dimensões de relações no tratamento da língua falada e da língua escrita. O autor aqui distingue: a) oralidade e letramento (como práticas sociais); b) fala e escrita (como modalidades de uso da língua).

Em "A perspectiva das dicotomias", Marcuschi esclarece que as representações dicotômicas da língua deram origem ao prescritivismo de uma única norma lingüística tida como padrão, representada na denominada norma culta, dividindo a língua falada e a língua escrita em dois blocos distintos.

No quinto tópico "A tendência fenomenológica de caráter culturalista" é apresentada como uma tendência que observa a natureza das práticas da oralidade versus escrita, realizando análises de cunho cognitivo, antropológico ou social. Marcuschi não acredita que a visão culturalista possa dar conta das relações lingüísticas, visto que a questão é analisada em sua estrutura macro e de modo amplo.

Quanto “A perspectiva variacionista”, sexto tópico, o autor a classifica como uma tendência intermediária entre as duas anteriores, cuja função é tratar do papel da escrita e da fala sob o ponto de vista dos processos educacionais, propondo um tratamento intermediário na relação entre padrão e não-padrão lingüísticos nos contextos de ensino formal. Segundo ele, 
nessa tendência não se faz uma distinção entre fala e escrita, mas sim uma observação de variedades lingüísticas distintas, que de alguma forma submetem-se a algum tipo de norma. Finaliza o tópico afirmando que fala e escrita não são dois dialetos, mas sim duas modalidades de uso da língua.

No sétimo tópico, referido como "Perspectiva sociointeracionista", Marcuschi trata das relações entre fala e escrita dentro da perspectiva dialógica. E salienta que este modelo tem a vantagem de perceber com maior clareza a língua como fenômeno interativo e dinâmico, voltado para as atividades dialógicas que caracterizam a fala; podendo ser uma das melhores saídas para a observação do letramento e da oralidade como práticas sociais.

O último tópico desse capítulo da obra, intitulado "Aspectos relevantes para a observação da relação fala e escrita" sintetiza essa primeira parte, salientando que a língua, seja na modalidade falada ou escrita, reflete a organização da sociedade. Por isso, é útil observar que fala não apresenta propriedades intrínsecas negativas, nem a escrita possui propriedades intrínsecas privilegiadas. Ambas são modos de representação cognitiva e social que se revelam em práticas específicas.

A segunda parte do livro denominada "Da fala para a Escrita: Processos de Retextualização" equivale a uma demonstração de como as atividades de retextualização podem ser realizadas. Está dividida em treze tópicos, nos quais o autor estabelece as suas idéias básicas sobre o que seja a atividade de retextualização na prática.

Logo no primeiro tópico o autor estabelece que o estudo diz respeito a apenas uma das possibilidades de retextualização, a que consiste em passar o texto falado para o escrito, excluindo as demais possibilidades: texto falado para outro, texto escrito para outro e texto escrito para texto falado.

Os tópicos relacionados com as operações de retextualização tratam sucessivamente dos vários conteúdos referentes a atividades de transcrição e transcodificação, no que se distingue do que o autor chama de retextualização.

O terceiro, das variáveis, sustenta as operações de retextualização, propondo a relação entre o produto do texto e a transformação. Outros conteúdos como as regras de editoração, o processo de transformação realizada em outros estudos anteriores, aspectos variados envolvidos na atividade de retextualização, de como se dá o fluxo dos processos de retextualização, o modelo proposto para as operações, a reestilização e a 
relexicalização em seus aspectos gerais, análises de alguns exemplos de atividades feitas são tratados ao longo dos tópicos.

No penúltimo deles, o autor trata de apresentar as perspectivas de trabalho, considerando a possibilidade de as diversas atividades de retextualização fazerem parte das aulas no ensino de língua.

No último tópico desse segundo capítulo, o autor tece as suas considerações finais, lembrando que a língua não é simplesmente um sistema de regras, mas como uma atividade do mundo sócio-cultural, um fenômeno que contribui criativamente para outras criações.

Em suma, a obra problematiza o mito da supremacia da escrita sobre a fala e discute outros preconceitos por nós cultuados, como a concepção de que a língua falada se realiza sem planejamento. Ao tentar desfazer estes mitos Antônio Marcuschi admite que oralidade e escrita sejam duas modalidades de uso da mesma língua, convivendo sob o esteio de sistemas e regras, mas com capacidade de expressar tudo o que podemos pensar. O trabalho realizado com este livro nos conduz a reavaliar o lugar da fala e da escrita nas sociedades contemporâneas, oferecendo-nos critérios de análise destas duas dimensões e capacitando-nos a usar a língua para produzir um efeito de sentido a ser utilizado numa dada situação.

Esta possibilidade analítica nos remete à obra de Ingedore Koch $O$ texto e a construção dos sentidos, cuja discussão se funda em questões relativas à produção do sentido comuns às modalidades escrita e falada, procurando descrever e explicar a capacidade do ser humano de interagir socialmente por meio de uma língua, das mais diversas formas e com os mais variados resultados. A leitura dessa obra certamente enriquecerá a prática de todos os que trabalham com a atividade de textualização na prática pedagógica. 